\title{
Learning Circumference and Area of Building with Video Media for Fourth Class Students of Elementary School
}

\section{Made Dewanda Sulaksana ${ }^{1}$, Kadek Yudiana ${ }^{2}$, Alexander Hamonangan Simamora ${ }^{3}$}

1,2 Program Studi Pendidikan Guru Sekolah Dasar, Universitas Pendidikan Ganesha, Singaraja, Indonesia

${ }^{3}$ Program Studi Teknologi Pendidikan, Universitas Pendidikan Ganesha, Singaraja, Indonesia

\section{AR T I C L E I N F O}

\section{Article history:}

Received September 02, 202

Revised September 04, 2021

Accepted October 28, 2021

Available online November 25, 2021

\section{Kata Kunci:}

Media Pembelajaran, Video,

Matematika

Keywords:

Learning media, Videos,

Mathematics

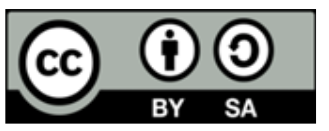

This is an open access article under the CC BY-SA license.

Copyright @ 2021 by Author. Published by Universitas Pendidikan Ganesha.

\begin{abstract}
A B S T R A K
Kurangnya penggunaan media pembelajaran yang menarik membuat siswa kurang aktif selama mengikuti proses pembelajaran daring. Untuk mengatasi hal tersebut perlu adanya pengembangan suatu media dalam proses pembelajaran. Penelitian ini bertujuan untuk menghasilkan video pembelajaran matematika pada topik keliling dan luas bangun datar kelas IV SD yang telah diuji keberterimaannya. Penelitian ini menggunakan jenis penelitian dan pengembangan (Research and Development). Penelitian ini menggunakan model ADDIE. Subjek pada penelitian ini adalah 2 ahli isi mata pelajaran, 2 ahli media dan ahli desain, dan 2 ahli praktisi untuk mengetahui validitas media video pembelajaran. sedangkan objek penelitiannya adalah validitas media video pembelajaran. Penelitian ini menggunakan metode kuesioner dan instrument rating scale sebagai sarana pengumpulan data. Berdasarkan hasil penelitian, 88\% dan 92\% merupakan skor yang diperoleh dari ahli isi mata pembelajaran dengan predikat baik dan sangat baik, 87\% dan 92\% merupakan skor yang diperoleh dari ahli desain dengan predikat baik dan sangat baik, $88 \%$ dan $88 \%$ merupakan skor yang diperoleh dari ahli media dengan predikat baik, serta 90\% dan 90\% merupakan skor yang diperoleh dari ahli praktisi dengan predikat sangat baik. Berdasarkan hasil tersebut, dapat disimpulkan bahwa pengembangan media video pembelajaran pada topik keliling dan luas bangun datar untuk siswa kelas IV SD dinyatakan valid dan layak digunakan dalam proses pembelajaran.
\end{abstract}

\section{A B S T R A C T}

The lack of use of interesting learning media makes students less active during the online learning process. To overcome this, it is necessary to develop a media in the learning process. This study aims to produce a video of learning mathematics on the topic of perimeter and area of flat shapes for fourth grade elementary school students that have been tested for acceptability. This study uses the type of research and development (Research and Development). This study uses the ADDIE model. The subjects in this study were 2 subject content experts, 2 media experts and design experts, and 2 practitioner experts to determine the validity of instructional video media. while the object of research is the validity of learning video media. This study uses a questionnaire method and rating scale instrument as a means of data collection. Based on the research results, $88 \%$ and $92 \%$ are scores obtained from subject matter content experts with good and very good predicates, $87 \%$ and $92 \%$ are scores obtained from design experts with good and very good predicates, $88 \%$ and $88 \%$ are scores obtained from media experts with good predicates, and $90 \%$ and $90 \%$ are scores obtained from expert practitioners with very good predicates. Based on these results, it can be concluded that the development of learning video media on the topic of circumference and area of flat shapes for fourth grade elementary school students is declared valid and feasible to use in the learning process.

\section{INTRODUCTION}

Education is very important for a nation. Adequate education will result in quality human resources (Siagian et al., 2020; Susilowati, 2018). Teachers become one of the important components in carrying out quality education. His ability to choose strategies, models, methods, and media in the learning process becomes one of the determinants of the success of the learning process (Suandewi et al., 2017; Widyaiswara 
et al., 2019; Wiji Hastuti et al., 2019). Included in the process of learning mathematics in elementary school. Mathematics is the science that is the basis in the development of modern technology, and plays an important role in various disciplines as well as advancing human thinking (Ananda, 2017). Ideally mathematics is taught through a learning process that is student-centered, prioritizes meaningfulness, and is oriented towards improving high-level thinking skills, such as: critical thinking, logical, systematic, and creative (Hardianto \& Baharuddin, 2019; Nainggolan et al., 2021; Oktaviani et al., 2018; Surya, 2017). This skill takes precedence in the 21st century learning process that will be the provision of students ready to compete in the world of work later (Boso et al., 2021; Lavi et al., 2021; Rovers et al., 2018; Sung, 2017). Further explained that the learning process must mean that the material taught should be informed by everyday events (Chauhan, 2017; Kenedi et al., 2018).

But in reality in the field, the learning process, especially mathematics, has not taken place optimally. This happens because of several obstacles such as lack of adequate media facilities, innovation from teachers in designing an interesting learning, and learning sources that are still abstract. The results of observations carried out in Katung state elementary school in the 2020/2021 school year obtained information that at the time of math learning, teachers have not used the media and only rely on books. The learning process like this takes place repeatedly which results in students feeling saturated in following the learning. Furthermore, through interviews with teachers of grade IV Katung state elementary school it is known that the cause of teachers not using the media during learning because teachers find it difficult to create media, besides the availability of media in schools is also very little. Some studies mention almost the same problem, namely: the learning process takes place less meaningfully, teachers dominate the learning process with lectures, teachers experience obstacles in terms of media procurement in accordance with the material taught (Fauzia, 2018; Hanifah et al., 2019; Cape \& Nababan, 2016). If the problem is not addressed immediately, it will certainly have a negative impact. In the short term, of course, the impact is the low learning outcomes of students' mathematics, and in the long term will certainly have an impact on the lace quality of Indonesian human resources compared to other countries.

Based on these problems, the thing that can be done is to strive for an ideal mathematics learning process. Efforts that can be done are to develop learning media. One of the appropriate learning media to be developed is video media. This media has advantages because, at the same time, it can display sound and images that give an exciting and more concrete impression, and the material presented becomes more systematic so that it is easy to use (Pradilasari et al., 2019; Sulfemi \& Mayasari, 2019; Wisada et al., 2019). Further explained the use of video as a medium makes the learning atmosphere more varied and certainly improves the quality of learning (Kurniawan et al., 2018; Vannisa Aviana Melinda et al., 2017). Other research results mention learning with video-assisted learning has a significant influence on improving student learning outcomes (Pramana \& Suarjana, 2019). The development of video media has actually been done in previous studies such as: video development for IPS learning; video for Hindu learning; and video for learning Theme 6 Subthema 2 for elementary students the video media results are valid and worthy to be developed (Tegeh et al., 2019; Yuanta, 2019).

Previous research findings stated that learning videos could facilitate students ' learning (Kawka et al., 2021; Layona et al., 2017; Nonthamand, 2020). Other research findings also state that learning videos can increase students' enthusiasm and motivation to learn (Kamelia, 2019; Lukman et al., 2019; Suryansah \& Suwarjo, 2016a).Other research findings also state that learning videos can improve student outcomes (Andriyani \& Suniasih, 2021; Fisnani et al., 2020; Pamungkas et al., 2018). However, the learning video developed in this study is different from previous research, namely the material taken about the circumference and area of flat wake, learning video media is divided into 3 parts, among others, opener, content, and cover. In the opening section there is an introduction to the learning video, then the identity of the creator, as well as the introduction of the material to be contained in the video. Then in the contents there is a presentation of material topics about the circumference and area of flat wakes that have been designed into the form of animation. And in the closing section there is a problem exercise, as well as a closing word to end the display of learning videos. The advantages of video media developed in this study is thatthisedia is packaged in the form of videos that can be played and issue animations with sounds according to the topic of the material developed so that it becomes more interesting and also equipped with exercises of questions and discussions that can facilitate students in learning. The purpose of this study is to analyze the video media developed so as to produce video media on the material keliling and flat wake area that is valid and feasible to be developed. The hope is that the resulting media can help teachers overcome media procurement constraints on math learning and can ultimately improve students' math learning outcomes. 


\section{METHOD}

This research uses this type of research and development (R\&D) using the ADDIE model. In this study, the product developed in the form of learning video media. This research focuses on the development of video learning media on the topic of traveling and broadly waking flat grade IV elementary school. As for the research steps of addie model development in this study, it can be seen in the following chart referenced from (Tegeh \& Jampel, 2017).

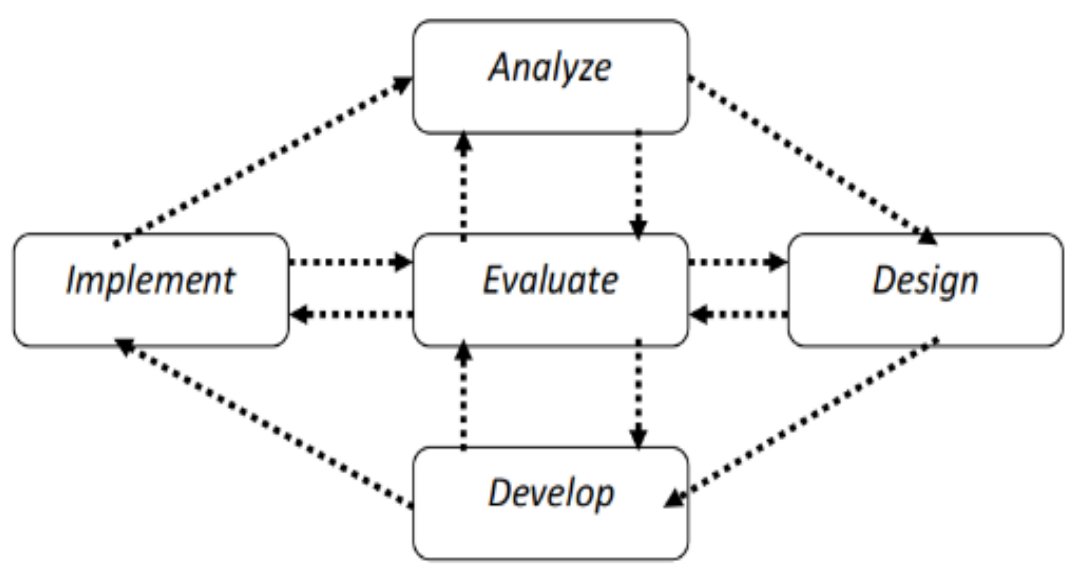

Picture 1. ADDIE Model Stages

The analysis stage is the stage of problem identification that is done to get information and analyze the problem. The activities carried out are analyzing the needs of developed media and analysis of student characteristics. This activity is done to find out the problems that occur in mathematical learning activities. In the analysis stage includes several stages that are implemented, namely the analysis of student characteristics, curriculum analysis, needs analysis, and media analysis. Needs analysis includes observation and dissemination of questionnaires to grade IV teachers in Katung state elementary school regarding the use of media in learning. Analysis of the characteristics of students who later use this media, so that it can be used as a picture in designing media that match the characteristics of the target student. Curriculum analysis is conducted with core competencies (KI), basic competencies (KD), and subject matter tailored to the student's book to find out the material developed. Media analysis is done by looking for guidelines on good media criteria or characteristics.

The second stage in the development of the ADDIE model is the design phase of this stage focusing on the material that will be packaged into the media, as well as the flow of material delivery in the learning video media. This design starts from determining the topic of material suitable for development in video media, then making a media design from the opening section, the selected topic material in the form of animated videos, problem exercises, and closings. After the design process is completed then continued by applying for guidance from the guidance lecturer to get input and advice related to the design that has been designed. The third stage in the development of the ADDIE model is the development stage. At this stage, the design that is prepared at the design stage is then developed into a learning video medium. Activities at this stage consist of the process of preparing materials/teaching materials, preparing interesting animations for students, making materials that are in accordance with the learning video that will be made, and the preparation of questions in the form of quizzes or student worksheets as assessment instruments. All the preparation is implemented into the learning video media developed in accordance with the learning materials in the syllabus. Then continued with the media testing stage by providing assessment sheets to experts consisting of two lecturers of media experts, two material experts and two teachers. Data obtained from the results of expert tests is then analyzed so that the validity of the learning video media that has been completed is made and then corrected if there are suggestions and inputs. While at the implementation stage and evaluation can not be implemented because it is hindered by time and financial constraints. The subjects in this study were 2 expert content subjects, 2 media experts and design experts, and 2 expert practitioners to find out the validity of video learning media. While the object of the research is the validity of the learning video media. The data collection method in this study is using questionnaire methods and the instrument used in this study is the Rating Scale instrument which is 1-5 (Ilhami \& Rimantho, 2017). The grid of validation sheets and learning video media validation instruments are presented in the following Table1,2,3,4. 
Table 1. Trial Instrument Grid for Subject Content Experts

\begin{tabular}{|c|c|c|}
\hline No. & Aspects & Indicators \\
\hline \multirow[t]{4}{*}{1} & \multirow{4}{*}{ Truth of Material Structure } & Conformity of indicators with basic competencies. \\
\hline & & Conformity of learning objectives with indicators. \\
\hline & & Conformity of the material with the purpose of learning. \\
\hline & & Learning objectives already use ABCD format \\
\hline \multirow[t]{4}{*}{2} & \multirow{4}{*}{ Accuracy of Material Content } & The truth of the material presented \\
\hline & & Accuracy of the material submitted \\
\hline & & Novelty of the material presented \\
\hline & & Accuracy of presentation of material based on existing facts \\
\hline \multirow[t]{2}{*}{3} & \multirow{2}{*}{ Correct Grammar Serving } & Accuracy of grammar used \\
\hline & & Accuracy of spelling writing on material \\
\hline 4 & $\begin{array}{l}\text { Punctuation is Presented } \\
\text { Appropriately }\end{array}$ & Accuracy of punctuation use on material \\
\hline \multirow[t]{5}{*}{5} & & $\begin{array}{l}\text { The level of breadth of the material according to the characteristics } \\
\text { of the student }\end{array}$ \\
\hline & Correctness of the & The initial material is able to relate to the student's initial \\
\hline & Appropriateness of the Level & knowledge \\
\hline & of Difficulty with the User & Depth of material presented \\
\hline & & $\begin{array}{l}\text { Illustration (example) in the learning media able to clarify the } \\
\text { material delivered. }\end{array}$ \\
\hline
\end{tabular}

Table 2. Trial Instrument Grid for Learning Media Design Experts

\begin{tabular}{|c|c|c|}
\hline No. & Aspects & Indicators \\
\hline & & Suitability of learning video media character layout \\
\hline 1 & Accuracy & Accuracy of interesting animation selection \\
\hline & & The material in the learning video is packaged in a row \\
\hline 2 & Clarity & $\begin{array}{l}\text { The language used is easy for students to understand.. } \\
\text { Clarity of description and discussion } \\
\text { Clarity of content provided }\end{array}$ \\
\hline 3 & Interest/Attention & $\begin{array}{l}\text { Videos motivate learning interests } \\
\text { Increase students attention to learning }\end{array}$ \\
\hline 4 & $\begin{array}{c}\text { The quality of the Test and Its } \\
\text { Assessment }\end{array}$ & Consistency of evaluation with learning objectives \\
\hline 5 & $\begin{array}{l}\text { It Can Have an Impact on } \\
\text { Students. }\end{array}$ & Facilitate students understanding of the material \\
\hline 6 & $\begin{array}{l}\text { It Can Have an Impact on } \\
\text { Teachers and Learning. }\end{array}$ & Make it easier for teachers in the learning process \\
\hline
\end{tabular}

Table 3. Trial Instrument Grid for Learning Media Experts

\begin{tabular}{|c|c|c|}
\hline No. & Aspects & Indicators \\
\hline 1 & Visual Quality & $\begin{array}{l}\text { The graphics displayed are very interesting } \\
\text { Animasi displayed is very interesting } \\
\text { The moving image shown (video) is very interesting }\end{array}$ \\
\hline 2 & Taking a Point of View & $\begin{array}{l}\text { Accuracy of viewpoints on video } \\
\text { Clarity of presenter's voice }\end{array}$ \\
\hline 3 & $\begin{array}{l}\text { Clarity of Narration Sound on } \\
\text { Musical Sound Effect }\end{array}$ & $\begin{array}{l}\text { Narrator's voice clarity } \\
\text { Suitability to use sound effect } \\
\text { Regularity of background music }\end{array}$ \\
\hline 4 & Suitability of Video Duration & Ideality of duration with target \\
\hline
\end{tabular}

Table 4. Trial Instrument Grid for Learning Media Practitioners

\begin{tabular}{ccl}
\hline No. & \multicolumn{1}{c}{ Aspects } & \multicolumn{1}{c}{ Indicators } \\
\hline 1 & Truth of Material Structure & Conformity of indicators with basic competencies. \\
Conformity of learning objectives with indicators. \\
Conformity of the material with the purpose of learning.
\end{tabular}




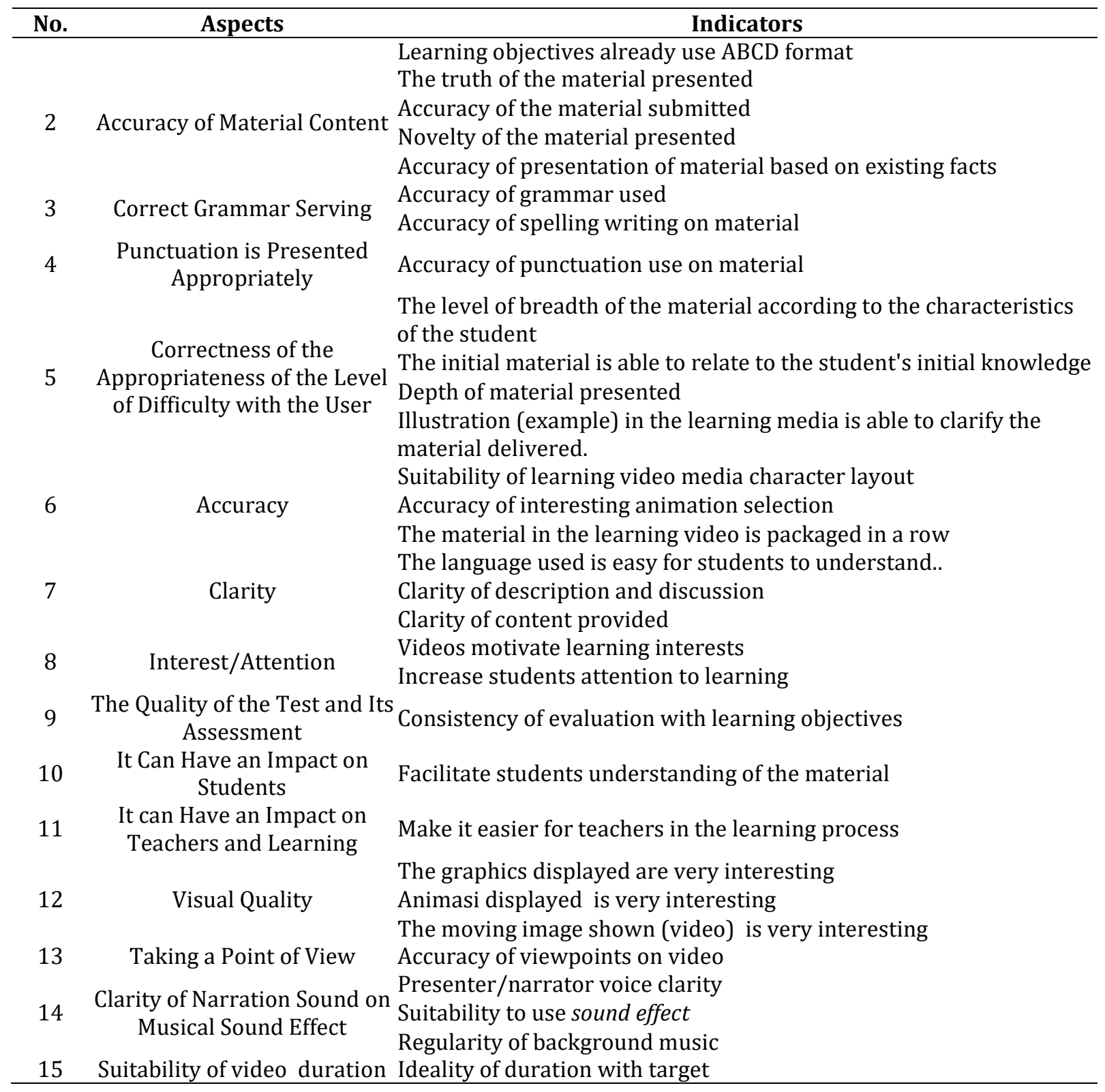

Instruments that have been prepared next conducted the stage of testing the validity of the contents. The content validity test is conducted to determine the degree of validity of the instrument using Gregory formula. After the data is collected using the instrument, then data analysis will be carried out with qualitative descriptive analysis techniques and quantitative descriptive analysis. Qualitative data is data obtained at the expert review stage in the form of suggestions and comments, then from the data is made improvements to the media developed in accordance with the suggestions and comments given so that it becomes a better medium. While quantitative data is data obtained at the expert review stage in the form of scores on the assessment sheet, then the data is calculated using Gregory formula that has been modified, to get the results of acceptance from the developed media. After obtaining the next score is converted with a table of criteria coefesien to the acceptance of the media. The criteria for the coeffesien of media acceptance can be seen in the following Table.

Table 5. Coefesien Criteria for Media Validity

\begin{tabular}{cc}
\hline Coefficient & Validity \\
\hline $0,81-1,00$ & Very High \\
$0,60-0,79$ & Tall \\
$0,40-0,59$ & Medium \\
$0,20-0,39$ & Low \\
$0,00-0,19$ & Very Low \\
\hline
\end{tabular}




\section{RESULT AND DISCUSSION}

Result

The research aims to produce video learning media on the topic of roving and extensive flat wakes in grade IV elementary school. The study ran from November 2020 to June 2021. This research uses the ADDIE model consisting of 5 stages, namely: analyse, design, development, implementation, and evaluation, but the implementation and evaluation stages are not implemented. The analysis stage is carried out through several stages, namely: needs analysis, curriculum analysis, analysis of student characteristics, and good media analysis. The needs analysis carried out on the development of media used in Katung state elementary school uses questionnaire methods and interviews shown to the teacher of class IV elementary school. Based on the results of the questionnaire obtained that: $100 \%$ of teachers stated that the material contained in the student's book is very minimal, $100 \%$ of teachers only use image media in learning activities, $100 \%$ of teachers state that learning media in schools is limited, and $100 \%$ of teachers state that Mathematics materials need to be developed depth of learning video media. The implementation of curriculum analyses is carried out by analyzing core competencies (KI), basic competencies (KD), and Indicators contained in teacher and student books that can be used as a reference in developing media. Basic Competencies and Competency Achievement Indicators are presented at the following.

Table 6. Basic Competencies and Indicators of Competency Achievement

\begin{tabular}{llll}
\hline \multicolumn{1}{c}{ KD } & \multicolumn{1}{c}{ Indicators } \\
\hline $3.9 \begin{array}{l}\text { Describe and determine the circumference } \\
\text { and area of square, rectangular, and } \\
\text { triangular areas. }\end{array}$ & 1.9 .1 & $\begin{array}{l}\text { Identify a variety of flat buildings of } \\
\text { squares, rectangles and triangles. }\end{array}$ \\
$\begin{array}{l}\text { Analyze how to calculate and determine } \\
\text { the circumference of squares, rectangles } \\
\text { and triangles. }\end{array}$ \\
\hline
\end{tabular}

The analysis of characteristics of elementary school students in piaget theory of cognitive development states that elementary students are at a concrete operational stage that at the time of learning requires concrete objects so that students are easier to understand learning materials. With this in the process of learning the learning media is very necessary existence. The existence of media makes it easier for students to better understand the material learned. While media analysis is carried out to obtain information about good media quality. In the development of this medium there are several criteria used that include aspects of cover, format, content, language, practicality, and effectiveness. Aspects of the cover include media identity and cover interest, format aspects include color, writing, letters, and layout, aspects of content include the compatibility of the material with indicators, media ability to explain the material, completeness of material, and the attractiveness of material to the media, language aspect criteria including language use, language profanity, sentence effectiveness, and word usage, as well as the practicality and effectiveness of media developed.

In the design stage researchers make the design of learning media products with reference to the analysis stage. Preparation of interactive video learning media content by creating a storyboard. Storyboard is an overview of the overall learning media that will be loaded in the application. Storyboard serves as a map-like guide to facilitate the media creation process (Novita, 2020; Winarni \& Astuti, 2020). Then the division of media content and learning materials in accordance with the learning plan. The content of the material is adjusted to the indicators and learning objectives. Media contains an explanation of the roving and extensive material of flat wake and its application in everyday life which is explained by additional animation created by creating studio with the help of adobe illustrator to create illustrations in learning videos. The media also contains examples of problems that are in accordance with indicators and learning objectives.

At the stage of development, the creation of developed media is carried out. The developed learning video media consists of the initialpart, the opening part, the exposure part of the flat wake rovingmaterial, the exposure part of the broad material of the flat wake, the closing part and the end of the learning video. The beginning of the video consists of an intro containing the text of the university name, developer identity, opening greeting, the title of the material so that students know what material to learn, as well as displaying basic competencies so that students know the competencies to be achieved after listening to the video. As for the initial display of learning video media on the topic of traveling and spacious flat wake for grade IV elementary school. The opening section of the learning video media features an opening by the narrator such as the provision of perceptions to explore the student initial knowledge. This section displays narrators who present material about the flat wake circumference, namely: an explanation of the circumference of 
flat wakes, rectangles, and triangles along with the introduction of examples that have flat wake properties, proof of the circumference of flat wake formulas and discussion of flat wake circumference. The closing section of this learning video media features a summary of material for students that aims to facilitate students in understanding flat wake materials and provide problems about flat wake in the student environment so that students can apply flat wake material learning into their daily lives. The results of the video that has been developed can be seen in the following image.
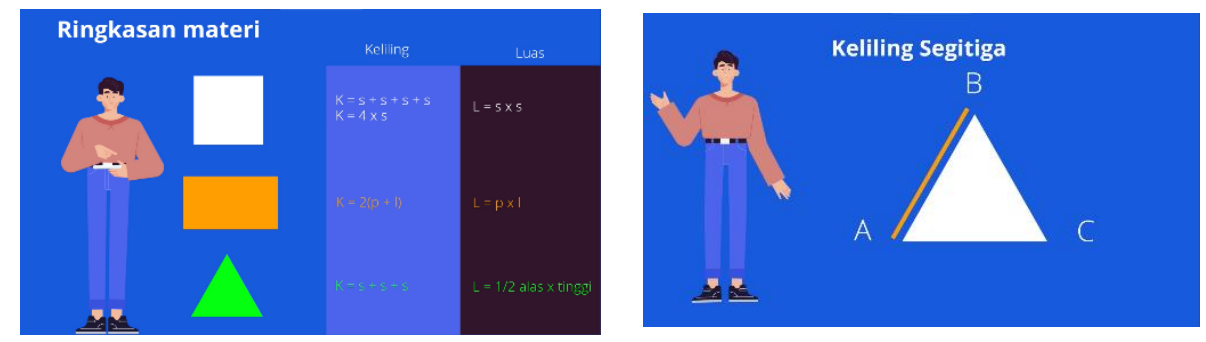

Picture 2. Learning Video Media

After the video development stage was carried out, the learning video media trial was conducted by six experts, namely two experts in the content of subjects, two design experts, two media experts and two practitioner experts. Data obtained from the results of media validity tests is then analyzed to find out the validity of the media that has been developed. Based on the results of tests that have been conducted obtained percentage results of $88 \%$ of experts in the content of learning eyes I with good categories, $92 \%$ of experts in the learning eye content II with excellent category, 87\% of design experts I with good categories, $92 \%$ of design experts II with excellent category, $88 \%$ of media experts I with good categories, and $88 \%$ of media II experts with good categories, $90 \%$ of practitioner I experts with excellent categories, $90 \%$ of practitioner II experts with excellent categories. Based on this, the video learning media on the topic of traveling and widely wake flat for students of grade IV Katung state elementary school has been tested for validity and deserves to be used in learning activities.

\section{Discussion}

The learning video media produced in this study was declared valid. This is based on the stage of development, validation of instruments and products in the form of media by teachers and lecturers as experts. Based on the predicate obtained, the developed media has been tested for validity and deserves to be used as a learning medium. Research on the development of video learning media on a mobile and spacious flat wake is feasible for use for grade IV students of Katung state elementary school, because elementary school students are at a concrete operational stage. The concrete operational stage of children can be grouped in concrete thinking means that they can understand if helped by the medium of images or concrete objects (Bujuri, 2018; Juwantara, 2019; Syar, 2020; Trianingsih, 2016) This can be overcome by the development of video learning media products based on the topic of roving and widely flat wake. This is in line with the research showed that, with the application of learning video media there was an increase in the average grade of student evaluation results (Fadhli, 2016; Sulfemi \& Mayasari, 2019; Widiyasanti \& Ayriza, 2018).

Based on the curriculum analysis that has been done, the learning video is in accordance with basic competencies (KD) and competency standards (SK). Meanwhile, the quality of video learning media and the aspect of operation is fairly easy. This is evidenced by the design and development of learning videos that are well implemented so as to create good results. It is evidenced from the results of product trial data that has been implemented that demonstration learning videos with concrete media are declared "Valid" so as to help teachers in carrying out learning (Arsyad \& Sulfemi, 2018; Batubara \& Batubara, 2020; Nurrohmah et al., 2018). In addition, the purpose of learning in the learning video media is in accordance with basic competencies and indicators. In addition, the language used in the learning video media is in accordance with the characteristics of learners. The findings of this study, in line with research conducted by (Melindaet al., 2018; Suryansah \& Suwarjo, 2016). The results showed that learning video media is worth using according to material experts and media experts with the category "good". Data from the feasibility test results of produk media video learning is obtained from the results of validation conducted by media experts and material experts.

In the application of this learning video has limitations that are only until it is implemented at the development stage only because of time and conditions limitations. Thus the development of mobile material videos and wide flat wakes is expected to be able to increase students understanding and 
knowledge of the surrounding material and the area of flat wake (Megawati \& Utami, 2020; Priantini, 2020; Wisada et al., 2019) . In addition, for other researchers can use this research as a reference and can develop similar research perfectly. The use of learning videos in grade IV elementary schools is suitable for improving students learning outcomes. The statement is supported by the results of research states that the use of learning media through image media on audio visuals/videos can improve students learning outcomes. In addition, there are shortcomings of the research that has been done (Nonthamand, 2020; Riwu et al., 2018; Yudhiantara \& Saehu, 2017). The deficiency lies in stages that cannot be implemented in accordance with all stages because it is hindered by time and cost.

The implications of this study are thatthis learning video can be used as a tool in the learning process, especially on the topic of traveling and widespread flat wake in grade IV elementary school. This medium can be used by students anywhere and anytime. In order for the learning process to be more effective teachers must understand the characteristics of the students being taught. The availability of learning video media on the topic of traveling and widespread flat wake can help teachers in conveying learning topics and students can understand the material and solve problems in learning easily. In addition, the advice that can be conveyed by researchers is that the existence of this learning video can help understand learning materials and increase student morale to be more active in learning activities. As for researchers like him, it is expected to be able to develop learning videos completely using the methods used when developing similar learning videos.

\section{CONCLUSION}

The development of learning video media on the topic of traveling and widely wake flat for students of grade IV elementary school Katung state has been tested for validity and worthy of use in Mathematics learning activities that emphasize innovative learning by presenting a new concept in the form of introduction of material about proving the formula of the perimeter and spacious flat wake and adjusting the media to the current learning conditions.

\section{REFERENCES}

Ananda, R. (2017). Penggunaan Media Audio Visual untuk Meningkatkan Hasil Belajar Pendidikan Kewarganegaraan Siswa Kelas IV SD Negeri 016 Bangkinang Kota. Jurnal Basicedu, 1(1), 21-30. https://doi.org/10.31004/basicedu.v1i1.149.

Andriyani, N. L., \& Suniasih, N. W. (2021). Development Of Learning Videos Based On Problem-Solving Characteristics Of Animals And Their Habitats Contain in Science Subjects On 6th-Grade. Journal of Education, 5(1), 37-47. https://doi.org/10.23887/jet.v5i1.32314.

Arsyad, A., \& Sulfemi, W. B. (2018). Metode Role Playing Berbantu Media Audio Visual Pendidikan dalam Meningkatkan Belajar IPS. Jurnal PIPSI (Jurnal Pendidikan IPS Indonesia), 3(2), 41. https: //doi.org/10.26737/jpipsi.v3i2.1012.

Batubara, H. H., \& Batubara, D. S. (2020). Penggunaan Video Tutorial untuk Mendukung Pembelajaran Daring di Masa Pandemi Virus Corona. Jurnal Madrasah Ibtidaiyah, 5(2), 78-84. https://doi.org/10. 31602/muallimuna.v5i2.2950.

Boso, C. M., van der Merwe, A. S., \& Gross, J. (2021). Students' and educators' experiences with instructional activities towards critical thinking skills acquisition in a nursing school. International Journal of Africa Nursing Sciences, 14, 100293. https://doi.org/10.1016/j.ijans.2021.100293.

Bujuri, D. A. (2018). Analisis Perkembangan Kognitif Anak Usia Dasar dan Implikasinya dalam Kegiatan Belajar Mengajar. LITERASI (Jurnal Ilmu Pendidikan), 9(1), 37. https: //doi.org/10.21927/literasi.2018.9(1).37-50.

Chauhan, S. (2017). A meta-analysis of the impact of technology on learning effectiveness of elementary students. Computers \& Education, 105, 14-30. https://doi.org/10.1016/j.compedu.2016.11.005.

Fadhli, M. (2016). Pengembangan Media Pembelajaran Berbasis Video Kelas IV Sekolah Dasar. Jurnal Dimensi Pendidikan Dan Pembelajaran, 2(2), 24-33. https://doi.org/10.24269/dpp.v3i1.157.

Fauzia, H. A. (2018). Penerapan Model Pembelajaran Problem Based Learning Untuk Meningkatkan Hasil Belajar Matematika Sd. Primary: Jurnal Pendidikan Guru Sekolah Dasar, 7(1), 40. https: //doi.org/10.33578/jpfkip.v7i1.5338.

Fisnani, Y., Utanto, Y., \& Ahmadi, F. (2020). The Development of E-Module for Batik Local Content in Pekalongan Elementary School. Innovative Journal of Curriculum and Educational Technology, 9(1), 40-47. https://doi.org/10.15294/IJCET.V9I1.35592.

Hardianto, H., \& Baharuddin, M. R. (2019). Efektifitas Penerapan Model Pembelajaran PAIKEM Gembrot terhadap Peningkatan Hasil Belajar Mahasiswa pada Mata Kuliah Pembelajaran Matematika 
Sekolah Dasar. Cokroaminoto Journal of Primary Education, 2(1), 27-33. https: //doi.org/10.30605/cjpe.212019.105.

Hastuti, H. W., Baedowi, S., \& Mushafanah, Q. (2019). Keefektifan Model Pembelajaran Numbered Heads Together Berbantu Media Panelpa (Papan Flanel IPA) Terhadap Hasil Belajar. International Journal of Elementary Education, 3(2), 108-115. https://doi.org/10.23887/ijee.v3i2.18513.

Ilhami, R. S., \& Rimantho, D. (2017). Penilaian Kinerja Karyawan dengan Metode AHP dan Rating Scale. Jurnal Optimasi Sistem Industri, 16(2). https://doi.org/10.25077/josi.v16.n2.p150-157.2017.

Juwantara, R. A. (2019). Analisis Teori Perkembangan Kognitif Piaget Pada Tahap Anak Usia Operasional Konkret 7-12 Tahun Dalam Pembelajaran Matematika. Jurnal Ilmiah Pendidikan Guru Madrasah Ibtidaiyah, 9(1), 27-34. https://doi.org/10.18592/aladzkapgmi.v9i1.3011.

Kamelia, K. (2019). Using Video as Media of Teaching in English Language Classroom: Expressing Congratulation and Hopes. Utamax : Journal of Ultimate Research and Trends in Education, 1(1), 3438. https://doi.org/10.31849/utamax.v1i1.2742.

Kawka, M., MH.Gall, T., Fang, C., Liu, R., \& Jiao, R. (2021). Intraoperative video analysis and machine learning models will change the future of surgical training. Intelligent Surgery, 1(1). https: //doi.org/10.1016/j.isurg.2021.03.001.

Kenedi, A. K., Hendri, S., Ladiva, H. B., \& Nelliarti. (2018). Kemampuan Koneksi Matematis Siswa Sekolah Dasar Dalam Memecahkan Masalah Matematika. Jurnal Numeracy, 5(2), 226-235. https://doi.org/10.46244/numeracy.v5i2.396.

Kurniawan, D., Kuswandi, D., \& Husna, A. (2018). Pengembangan Media Video Pembelajaran Pada Mata Pelajaran Ipa Tentang Sifat Dan Perubahan Wujud Benda Kelas Iv Sdn Merjosari 5 Malang. JINOTEP (Jurnal Inovasi Dan Teknologi Pembelajaran) Kajian Dan Riset Dalam Teknologi Pembelajaran, 4(2), 119-125. https://doi.org/10.17977/um031v4i22018p119.

Lavi, R., Tal, M., \& Dori, Y. J. (2021). Perceptions of STEM alumni and students on developing 21st century skills through methods of teaching and learning. Studies in Educational Evaluation, 70, 1-11. https: //doi.org/10.1016/j.stueduc.2021.101002.

Layona, R., Yulianto, B., \& Turnadi, Y. (2017). Authoring Tool for Interactive Video Content for Learning Programming. Procedia Computer Science, 116, 37-44. https://doi.org/10.1016/j.procs.2017.10.006.

Lukman, A., Hayati, D. K., \& Hakim, N. (2019). Pengembangan Video Animasi Berbasis Kearifan Lokal pada Pembelajaran IPA Kelas V di Sekolah Dasar. Elementary: Jurnal Ilmiah Pendidikan Dasar, 5(2), 153. https://doi.org/10.32332/elementary.v5i2.1750.

Megawati, \& Utami. (2020). English Learning with Powtoon Animation Video. Journal of Education Technology, 4(2), 110. https://doi.org/10.23887/jet.v4i2.25096.

Melinda, V. A., Degeng, N. S., \& Kuswandi, D. (2018). Pengembangan Media Video Pembelajaran Ips Berbasis Virtual Field Trip (Vft) Pada Kelas V Sdnu Kratonkencong. JINOTEP (Jurnal Inovasi Dan Teknologi Pembelajaran): Kajian Dan Riset Dalam Teknologi Pembelajaran, 3(2), 158-164. https: //doi.org/10.17977/um031v3i22017p158.

Melinda, Vannisa Aviana, Degeng, I. N. S., \& Kuswandi, D. (2017). Pengembangan Media Video Pembelajaran IPS Berbasis Virtual Field Trip (VFT) Pada Kelas V SDNU Kratonkencong. JINOTEP (Jurnal Inovasi Dan Teknologi Pembelajaran): Kajian Dan Riset Dalam Teknologi Pembelajaran, 3(2), 158-164. https: //doi.org/10.17977/um031v3i22017p158.

Nainggolan, M., Tanjung, D. S., \& Simarmata, E. J. (2021). Pengaruh Model Pembelajaran SAVI terhadap Hasil Belajar Matematika Siswa di Sekolah Dasar. Jurnal Basicedu, 5(4), 2617-2625. https: //doi.org/10.31004/basicedu.v5i4.1235.

Nonthamand, N. (2020). Guideline to develop an instructional design model using video conference in open learning. International Journal of Emerging Technologies in Learning, 15(3), 140-155. https://doi.org/10.3991/ijet.v15i03.10842.

Novita, I. (2020). Pengembangan Bahan Ajar Menulis Teks Cerpen Berdasarkan Teknik Storyboard pada Siswa Kelas XI SMA. Diglosia: Jurnal Kajian Bahasa, Sastra, Dan Pengajarannya, 3(1), 46-52. https: //doi.org/10.30872/diglosia.v3i1.29.

Nur Millati Hanifah, M. A. K. B. M. A. B. (2019). Pengaruh Model Open Ended Problem Berbantu Media Kotak Telur Pelangi ( Kotela ) Terhadap Hasil Belajar. Journal of Education Technology., 3(3), 1-137. https://doi.org/10.23887/jet.v3i3.21734.

Nurrohmah, F., Putra, F. G., \& Farida, F. (2018). Development of Sparkol Video Scribe Assisted Learning Media. Formatif: Jurnal Ilmiah Pendidikan MIPA, 8(3), 233-250. https://doi.org/10.30998/formatif.v8i3.2613.

Oktaviani, W., Kristin, F., \& Anugraheni, I. (2018). Penerapan model pembelajaran discovery learning untuk meningkatkan kemampuan berpikir kritis dan hasil belajar matematika siswa kelas 5 SD. Jurnal 
Basicedu, 2(2), 5-10. https://doi.org/10.31004/basicedu.v2i2.137.

Pamungkas, A. S., Ihsanudin, I., Novaliyosi, N., \& Yandari, I. A. V. (2018). Video Pembelajaran Berbasis Sparkol Videoscribe: Inovasi Pada Perkuliahan Sejarah Matematika. Prima: Jurnal Pendidikan Matematika, 2(2), 127. https://doi.org/10.31000/prima.v2i2.705.

Pradilasari, L., Gani, A., \& Khaldun, I. (2019). Pengembangan Media Pembelajaran Berbasis Audio Visual pada Materi Koloid Untuk Meningkatkan Motivasi dan Hasil Belajar Siswa SMA. Jurnal Pendidikan Sains Indonesia, 7(1), 9-15. https://doi.org/10.24815/jpsi.v7i1.13293.

Pramana, I. P. Y., \& Suarjana, I. M. (2019). Pengaruh Model Pembelajaran Time Token Berbantuan Media Video Terhadap Hasil Belajar IPA Kelas V SD. Journal of Education Technology, 2(4), 137. https: //doi.org/10.23887/jet.v2i4.16425.

Priantini, D. A. (2020). The Development Of Teaching Video Media Based On Tri Kaya Parisudha In Educational Psychology Courses. Journal of Education Technology, 4(4). https://doi.org/10.23887/jet.v4i4.29608.

Riwu, I. U., Laksana, D. N. L., \& Dhiu, K. D. (2018). Pengembangan Bahan Ajar Elektronik Bermuatan Multimedia Pada Tema Peduli Terhadap Makhluk Hidup Untuk Siswa Sekolah Dasar Kelas Iv Di Kabupaten Ngada. Journal of Education Technology, 2(2), 56. https://doi.org/10.23887/jet.v2i2.16182.

Rovers, S. F. E., Clarebout, G.Rovers, S. F. E., Clarebout, G., Savelberg, H. H. C. M., \& van Merriënboer, J. J. G. (2018). Improving student expectations of learning in a problem-based environment. Computers in Human Behavior, 87, 416-423. https://doi.org/10.1016/j.chb.2018.02.016, Savelberg, H. H. C. M., \& van Merriënboer, J. J. G. (2018). Improving student expectations of learning in a problembased environment. Computers in Human Behavior, 87, 416-423. https://doi.org/10.1016/j.chb.2018.02.016.

Suandewi, N. P., Dibia, I. K., \& Dharsana, I. K. (2017). Pengaruh Model Pembelajaran Nos Untuk Meningkatkan Hasil Belajar IPA Melalui Lesson Study Siswa Kelas V. Mimbar PGSD, 5(3), 1-11. https://doi.org/10.23887/jjpgsd.v5i3.12061.

Sulfemi, W. B., \& Mayasari, N. (2019). Peranan Model Pembelajaran Value Clarification Technique Berbantuan Media Audio Visual Untuk Meningkatkan Hasil Belajar IPS. Jurnal Pendidikan, 20(1), 53-68. https://doi.org/10.33830/jp.v20i1.235.2019.

Sung, E. (2017). The influence of visualization tendency on problem-solving ability and learning achievement of primary school students in South Korea. Thinking Skills and Creativity, 26, 168-175. https: //doi.org/10.1016/j.tsc.2017.10.

Surya, Y. F. (2017). Penerapan model pembelajaran problem based learning untuk meningkatkan hasil belajar matematika siswa kelas IV SDN 016 Langgini Kabupaten Kampar. Jurnal Cendekia: Jurnal Pendidikan Matematika, 1(1), 38-53. https://doi.org/10.31004/cendekia.v1i1.7.

Suryansah, T., \& Suwarjo, S. (2016a). Pengembangan Video Pembelajaran Untuk Meningkatkan Motivasi Dan Hasil Belajar Kognitif Siswa Kelas Iv Sd. Jurnal Prima Edukasia, 4(2), 209. https: //doi.org/10.21831/jpe.v4i2.8393.

Suryansah, T., \& Suwarjo, S. (2016b). Pengembangan Video Pembelajaran Untuk Meningkatkan Motivasi Dan Hasil Belajar Kognitif Siswa Kelas IV SD. Jurnal Prima Edukasia, 4(2), 209. https: //doi.org/10.21831/jpe.v4i2.8393.

Sutama, A. (2014). Penerapan Teori Behavioral dengan Teknik Modeling untuk Meningkatkan Kemandirian Belajar Siswa Kelas AK C SMK Negeri 1 Singaraja. Jurnal Ilmiah Bimbingan Konseling, 2(1). https: //doi.org/10.23887/jibk.v2i1.3960.

Syar, N. I. (2020). Analisis Kemampuan Operasi Logik Siswa Sma Dalam Mata Pelajaran Fisika Pada Tahap Operasional Formal. Pedagogik: Jurnal Pendidikan, 7(2), 459-494. https://doi.org/10.33650/pjp.v7i2.1516.

Tegeh, I. M., Simamora, A. H., \& Dwipayana, K. (2019). Pengembangann media video pembelajaran dengan model pengembangan 4D pada mata pelajaran Agama hindu. Jurnal Mimbar Ilmu, 24(2). https: //doi.org/10.23887/mi.v24i2.21262.

Trianingsih, R. (2016). Pengantar Praktik Mendidik Anak Usia Sekolah Dasar. Al Ibtida: Jurnal Pendidikan Guru MI, 3(2), 197. https://doi.org/10.24235/al.ibtida.snj.v3i2.880.

Widiyasanti, M., \& Ayriza, Y. (2018). Pengembangan Media Video Animasi untuk Meningkatkan Motivasi Belajar dan Karakter Tanggung Jawab Siswa Kelas V. Jurnal Pendidikan Karakter, 8(1), 1-16. https://doi.org/10.21831/jpk.v8i1.21489.

Widyaiswara, G. P., Parmiti, D. P., \& Suarjana, I. M. (2019). Pengaruh Model Pembelajaran Contextual Teaching and Learning terhadap Hasil Belajar IPA. International Journal of Elementary Education, 3(4), 389-395. https://doi.org/10.23887/ijee.v3i4.21311.

Winarni, R., \& Astuti, E. R. P. (2020). Pengaruh Penggunaan Media Pembelajaran Storyboard Terhadap 
Kreativitas Belajar Sisiwa Pada Mata Pelajaran Seni Budaya. Jurnal Teknologi Pendidikan: Jurnal $\begin{array}{llll}\text { Penelitian Dan Pengembangan } & \text { 4(2), }\end{array}$ https://doi.org/10.33394/jtp.v4i2.2249.

Wisada, P. D., Sudarma, I. K., \& Yuda S, A. I. W. I. (2019). Pengembangan Media Video Pembelajaran Berorientasi Pendidikan Karakter. Journal of Education Technology, 3(3), 140. https://doi.org/10.23887/jet.v3i3.21735.

Yuanta, F. (2019). Pengembangan Media Video Pembelajaran Ilmu Pengetahuan Sosial pada Siswa Sekolah Dasar. Jurnal Pendidikan Dasar, 1(2). https://doi.org/http://dx.doi.org/10.30742/tpd.v1i02.816.

Yuanta, F. (2020). Pengembangan Media Video Pembelajaran Ilmu Pengetahuan Sosial pada Siswa Sekolah Dasar. Trapsila: Jurnal Pendidikan Dasar, 1(02), 91. https://doi.org/10.30742/tpd.v1i02.816.

Yudhiantara, R. A., \& Saehu, A. (2017). Mobile-Assisted Language Learning (MALL) in Indonesian Islamic Higher Education. IJELTAL (Indonesian Journal of English Language Teaching and Applied Linguistics), 2(1), 21-31. https://doi.org/10.21093/ijeltal.v2i1.52. 